\title{
An Exploration of Transformational Leadership Preferences Among Women Sports Leaders in the Kingdom of Bahrain
}

Authors' contribution:

A) conception and design of the study

B) acquisition of data

C) analysis and interpretation of data

D) manuscript preparation

E) obtaining funding

\section{Latifa Abdalla}

Ministry of Education, Kingdom of Bahrain

ABSTRACT

The topic of leadership has attracted considerable interest amongst academics and practitioners. Much of the interest in the area of leadership is based on explicit and implicit claims that leadership styles are linked to organizational performance. This study aimed to examine the transformational leadership style among women sports leaders in the Kingdom of Bahrain. A total of 16 female sports leaders from the Kingdom of Bahrain participated in this study. The Multi-factor Leadership Questionnaire (MLQ) was used to determine the transformational leadership style of individuals. A demographic questionnaire was also administered to collect participants' personal data. The results indicated that transformational leadership style is moderate among women sports leaders in the Kingdom of Bahrain, thus we need to develop the leadership skills of women sports leaders in the Kingdom of Bahrain.

KEYWORDS transformational leadership, Women Leaders, Kingdom of Bahrain

\section{Introduction}

On a daily basis, the business of sports faces an ever changing and dynamic environment all over the world. Leaders can create a supportive environment in which people can grow, thrive, and work with one another (Fullan, 2003). Leaders can always expect a demand for change that comes from both inside and outside an organization (Kouzes \& Posner, 2003). By definition, leadership is a collective or group process whereby individuals work towards a common goal (Fullan, 2000). Organizations adjust themselves according to these environmental changes through incremental and evolutionary changes. Management of such change requires new management qualities. One of these qualities is a transformational leadership style that leads to positive changes in those who follow. Transformational leaders are generally energetic, enthusiastic, and passionate. Not only are these leaders concerned and involved in the process, but they are also focused on helping every member of the group succeed.

Bass (1990) suggested that transformational leaders build genuine trust, concentrate on terminal values such as integrity and fairness, and are concerned about doing what is right and honest. On the other hand, researchers indicate that a transformational leader recognizes and exploits a potential follower's existing need or demand. This suggests that once the leader recognizes the follower's need(s), the leader is able to persuade the follower. Research on the paradigm of transformational leadership has proven to be slightly 
greater. A variety of studies have cited organizational studies demonstrating that the behaviors of transformational leaders are positively related to employee satisfaction, self-reported effort, and job performance.

Leadership received interest in the area administrative work due to its importance in the completion of administrative tasks and goals achieved in institutions. The success or failure of these institutions due to the success of administrative leaders in their businesses through fulfilling the roles and duties entrusted to them, as well as their contribution to the development of their organizations according to their abilities and aptitudes, enables them to influence others to achieve organizational goals (Riggio, 2009).

Bahraini women no longer played the role in order to achieve the Renaissance society as it once was. Instead, they have become a valuable capacity for the society. This vast accomplishment has been confirmed by statistics and the gains made by women under the Covenant reformist King Hamad bin Isa Al Khalifa.

Bahraini women have accomplished many achievements in various fields in this prosperous era of His Majesty the King as a result of their access to rights under the constitution. These rights are affirmed and ensured in Article V (reconciling the duties of women towards the family and her work in the community, and economic and cultural equality with men in the political and social realms without prejudice to the provisions of Islamic law) (Manal, 2011). As part of the march, the comprehensive reforms for women included prominent, pivotal, and sophisticated roles. This made these reforms a model for Arab women: women capable of having a positive impact in building the society. This could especially be seen after women held several official positions, participated in decision-making processes in government ministries, and provided outstanding contributions to various political, economic, and social affairs. This study thus aimed to examine the transformational leadership style of women sports leaders in the Kingdom of Bahrain.

\section{Material and Methods}

\section{Participants}

The sample comprised 16 women sports leaders from the Kingdom of Bahrain who worked in sport and educational organizations in Bahrain (higher education, general education, and sports federations). A demographic questionnaire was administered to collect participant personal data.

\section{Instrument}

The Multi-factor Leadership Questionnaire (MLQ) was used to determine the transformational leadership style of individuals based on seven factors: idealized influence, inspirational motivation, intellectual stimulation, individualized consideration, contingent reward, management-by-exception, and laissez-faire leadership. The MLQ presents itself as more of a precise or measured way of assessing leadership factors and how individuals in the leader's sphere of influence are transformed. The score for each factor is determined by summing three specified items on the questionnaire. Score Range: High=9 to 12, Moderate $=5$ to 8 , Low $=0$ to 4

\section{Statistical Analysis}

All statistical analyses were calculated with the SPSS statistical package. The results are reported as means and standard deviations (SD). The level of $\mathrm{p}<0.05$ was considered statistically significant.

\section{Results}

Table 1 shows the age and leadership experience of the subjects. No significant differences were observed for the subjects. Data in Table 2 show that the level of transformational leadership is moderate. 
Table 1. Subject's age, work experience, and leadership experience $(n=16)$

\begin{tabular}{ll}
\hline Variables & Mean \pm SD \\
\hline Age (years) & $5.65 \pm 51.76$ \\
Work experience & $5.34 \pm 27.41$ \\
Leadership experience & $8.14 \pm 5.16$ \\
\hline Source: own study.
\end{tabular}

Source: own study.
Table 2. Biochemical variables for three groups

\begin{tabular}{lccl}
\hline Variables & Mean \pm SD & Rank & Level \\
\hline Idealized Influence & $11.85 \pm 1.54$ & 1 & High \\
Inspirational Motivation & $6.47 \pm 1.54$ & 5 & Moderate \\
Intellectual Stimulation & $4.56 \pm 1.22$ & 7 & Low \\
Individualized & $7.28 \pm 1.1$ & 4 & Moderate \\
Consideration & & & \\
Contingent Reward & $10.28 \pm 2.64$ & 2 & High \\
Management-by- & $4.8 \pm 1.75$ & 6 & Low \\
exception & & & \\
Laissez-faire Leadership & $7.76 \pm 1.36$ & 3 & Moderate \\
Total score & $6.00 \pm 1.06$ & & Moderate \\
Source: own study. & & &
\end{tabular}

\section{Discussion}

The results of this study showed that the level of transformational leadership is moderate, and that the high score in idealized influence factor revealed the charismatic leader.

Avolio (1999) refers to transformational leaders as charismatic leaders. The behavior of a charismatic leader, according to Howell and Frost, produces higher performance, greater satisfaction, and greater role clarity when compared the behavior of a directive leader. Similar results were reported in other research studies (Bass \& Avolio, 1994; Bass, 1990).

Ayman (1997) suggested that educational system administrators, just as with corporate America executives, now more than ever understand the importance of having leaders that represent the growth and changes in an institution's diversity, especially considering that there are many qualified women currently in the academic marketplace.

Bass (1990) indicated that when transformational leaders see themselves in a win-lose negotiation, they try to convert it to a win-win situation simply by solving the problem. Bass further pointed out that transformational leaders strive to achieve true consensus in aligning individual and organizational interests. According to Fullan (2001), leaders are more influential when using transformational leadership than they are with traditional, control-based leadership styles such as transactional leadership.

Many researchers assert that the role of the leader in an organization largely depends on the organizational culture. It is also often argued that a leader's assumptions, beliefs, and values are very important to the leader in choosing a leadership style. The leader's personality, situation, and problem at hand will many times determine how the leader handles any given situation (Antonakis et al., 2004). Different leadership styles can be identified within management and supervisory techniques. However, a leadership style preference has its own set of characteristics that leaders use differently (Bass \& Avolio, 1994).

\section{Conclusion}

On the basis of research and analysis, the results indicate we need to develop women sports leaders in the Kingdom of Bahrain in the area of leadership skills.

\section{REFERENCES}

Antonakis, J., Cianciolo, A.T., Sternberg, R.J. (2004). The nature of leadership. Thousand Oaks, CA: Sage.

Avolio, B.J. (1999). Full leadership development: Building vital forces in organizations. Thousand Oaks, CA: Sage.

Ayman, R. (1997). Leadership and the glass ceiling. In K. Cushner \& R.W. Brislin (Eds.), Improving intercultural Interactions: Modules for cross-cultural training programs, vol. 3. (pp. 74-87). Sage Publications.

Bass, B. M. (1990). From Transactional to Transformational Leadership: Learning to Share a Vision. Organizational Dynamics, 18(3), 9-31. 
Bass, B.M., Avolio, B.J. (1994). Improving organizational effectiveness through transformational leadership. Thousand Oaks, CA: Sage.

Fullan, M. (2000). Educational leadership. San Francisco: Jossey-Bass.

Fullan, M. (2001). Leading in a culture of change. San Francisco: Jossey-Bass.

Fullan, M. (2003). The moral imperative of school leadership. Thousand Oaks, CA: Corwin.

Kouzes, J., Posner, B. (2003). The leadership challenge. San Francisco: Jossey Bass.

Manal Abdulla (2011). The leadership style of women in the Bank of Bahrain and Kuwait in the Kingdom of Bahrain. Bahrain, Kingdom of Bahrain: College of Administrative and Financial Sciences, Department of General Management, AMA International University.

Riggio, R.E. (2009). Are you a transformational leader? Psychology Today. Retrieved from http://blogs.psychology today.com/blog/cutting-edge-leadership/200903/are-you-transformational-leader

AUTHOR'S ADDRESS: $\quad$ Latifa Abdalla

Head of the Girl Scouts Department

Ministry of Education

Building Al Istiklal Street 43

Kingdom of Bahrain

Email: dr.latifaalgoud@ hotmail.com 